\title{
The effect of free cash flow (FCF) on agency cost and financial performance in financial sector companies registered in indonesia stock exchange (BEI) 2015-2016
}

\author{
Agung Purnawarman, Puji Handayati* \\ Universitas Negeri Malang, Jl. Semarang No. 5 Malang, Jawa Timur, Indonesia \\ *Corresponding author, Surel: puji.handayati.fe@um.ac.id
}

Paper received: 1-4-2021; revised: 22-4-2021; accepted: 29-4-2021

\begin{abstract}
The company not only aims to seek profit, but also to maximize the prosperity of its shareholders by maximizing the value of the company. Within the company, there are three people who have different interests, namely, company owners, shareholders, and managers. When the company generates free cash flow, there will be differences in the interests of the parties who make the work contract and create a conflict that will cause the company to pay costs, which is called agency cost. The result of this difference in interest can also affect the company's financial performance because the company's finances are not going well. The purpose of this study was to determine the effect of free cash flow (FCF) on agency cost and financial performance in financial sector companies listed on the IDX in 2015-2016. The type of research used in the research is Explanatory Research, with a population of 83 companies listed on the Indonesian stock exchange in the financial sector in 2015-2016. The sampling technique used the purposive sampling method of as many as 61 companies listed on the Stock Exchange in the financial sector 2015-2016. The analytical tool used in this study is a simple regression test. Based on the results of the analysis, it is found that free cash flow (FCF) has a positive and significant effect on agency cost in financial sector companies listed on the IDX 2015-2016 of $33.7 \%$ and free cash flow (FCF) has a positive and significant effect on performance. finance by $34.0 \%$.
\end{abstract}

Keywords: free cash flow (FCF); agency cost; financial performance

\section{Introduction}

The company not only has the objective of being profit-oriented, but is more about maximizing the prosperity of its shareholders by maximizing firm value. The company's goal in optimizing the company's value can be achieved by carrying out the functions of financial management. The welfare of the company can be seen from the company's performance (firm performance). The company's performance can be seen from the company's ability to generate profits in the use of resources. Profit can provide a positive signal about the prospects of the company in the future, because profit is a measurement of the company's performance. The measurement can be seen from the profit obtained from activities in utilizing resources in the form of company assets.

Jensen and Meckling (1976) describe a company as a set of contracts between the owner of capital (principal) and the manager (agent). Each stakeholder has different interests, the owner has an interest in maximizing his wealth through dividend payments resulting from profitable investments. While management has an interest in the size and growth of the company, because the size and growth of the company will provide job security, promotion, and compensation for managers (Mardatilah, 2013). Managers are expected to manage the company in accordance with the main objective of the company, namely increasing company value through increasing the prosperity of the owners or shareholders (Bringham and 
Houston, 2006). The existence of a conflict of interest due to different goals between owners and managers like that will create a problem known as agency problem (agency conflict). Agency problems are based on human nature that prioritizes self-interest (Eisenhard 1989, in Jogiyanto, 2007).

The potential that managers will manage the company more for their own interests and not for the interests of the owners creates an incentive for shareholders to create various governance tools designed to monitor managers and ensure that the company will be managed in the best interests of the owners. Costs arising from a potential conflict of interest are known as agency costs (Jensen and Meckling, 1976). As in an agency relationship that can lead to agency conflict, a work contract is required, where this regulates the proportion of rights and obligations of each party, in this case emerges agency theory which has the function of designing appropriate work contracts to align the interests of both. both the principal and the agent are involved in resolving agency conflicts so as to minimize agency costs (Wang, 2010).

On the one hand, the shareholder (principal) expects the agent to maximize firm value so that free cash flow can be distributed as dividends received by shareholders. But on the other hand, the management (agent) wants free cash flow to be used for business expansion, especially if the company has investment opportunity a high. The free cash flow size of the owned by the company is the main attraction for each stakeholder to be used in their respective interests. High free cash flow indicates a company is able to pay debts to creditors, pay dividends to investors, and the company can grow its business. Managers have a tendency to take advantage of free cash flow as an instrument to develop a business so that the company grows, while owners want a high share of dividends from the amount of free cash flow. White et al. (2003: 68) argue that the greater the free cash flow available in the company, the healthier the company will be because it has cash available for growth, debt payments, and dividends.

Apart from affecting agency cost, free cash flow also affects the financial performance of a company. When a company has generated an excessive surplus (free cash flow) and management tends to misuse the existing free cash flow, which can lead to increased agency costs, inefficient allocation of resources, and wrong investments that result in decreased company performance. . Brush et al (2000) found that sales growth is most beneficial for companies that lack cash flow, but not necessarily for companies with free cash flow sufficient. Chung et al (2005) also found that excessive FCF may have a negative impact on firm profitability and stock valuation and thus increase agency costs. The findings of Wang (2010) that free cash flow has a significant positive effect on ROA and ROE. Among the six variables, namely agency costs, total asset turnover, operating expense ratios, and administrative costs ratios are statistically significant to operating performance, while R\&D costs and volatility are not statistically significant to operating performance. Thus, if free cash flow a higher will decrease the company's operating performance, the total asset turnover and operating cost ratio will give rise to agency costs.

Several previous studies have found empirical evidence for the hypothesis free cash flow on agency cost and financial performance. Chu (2011) found a positive relationship between free cash flow and agency cost. However, a different result was found by Wang (2010) who tested the effect of free cash flow on agency cost and financial performance in public companies listed on the Taiwan Stock Exchange. Wang (2010) uses several proxies for agency cost, namely asset turnover, operating ratio, administration ratio, research \& development ratio, operating 
income volatility, and net income volatility. The results of his research found that free cash flow had a negative effect on agency cost as proxied by operating ratio, administration ratio, and research \& development ratio. However, Wang (2010) found different results when using asset turnover as a proxy for agency cost. He found that free cash flow has an effect on reducing asset turnover, which indicates an increase in agency cost.

Piramita (2012) if a company has high free cash flow, the company tends to have a better performance than companies that have low free cash flow . According to Wang (2010), there is a significant positive relationship between free cash flow and financial performance. Wang (2010) uses return on assets (ROA) as a proxy for financial performance. ROA is a measure of a company's profitability, where the greater the ROA the greater the company's ability to generate profits for shareholders.

Several previous studies have also found aeffect of free cash flow negative on financial performance. This can occur when large free cash flows are available but there are few profitable investment opportunities, which will allow management to abuse the free cash flow under the manager's authority to increase the size of the company through unnecessary investments or with a negative NPV. (overinvestment). Investing in a project with a negative NPV will not increase firm value because the company's profitability in the long run will be lower (Chung et al. 2005) and the sales growth performance will be lower in companies with free cash flow (Brush et al. 2000). Consistent results were also found by Richardson (2006) and Yuan and Jiang (2008) who found a positive relationship between free cash flow and overinvestment. However, in contrast to these findings, Wang (2010) found a significant positive relationship between free cash flow and financial performance and failed to support the hypothesis free cash flow from

Jen- sen (1986). In his test, Wang (2010) uses return on assets (ROA) and return on equity (ROE) as proxies of financial performance. These results do not support the hypothesis free cash flow from Jensen (1986) and indicate that the presence of free cash flow in the company will increase investment opportunities that will generate more value for the company. This study uses one of the profitability ratios, namely ROA as an indicator of financial performance, because this variable shows a better performance measurement in several previous studies. Return On Assets (ROA) as a proxy for financial performance. Return On Assets illustrates how much the ability of the assets owned by the company to generate profits..

\section{Method}

\subsection{Research Design}

Type of research is Explanatory Research, which explains the relationship between the independent variable and the dependent variable through hypothesis testing. According to Sekaran (2006) hypothesis testing is a type of research that explains some of the relationships and influences between variables, understands the differences between groups, and the independence between variables in a situation. In testing the research hypothesis, two separate research models were used. The first research model is used to examine the H1 hypothesis, namely that free cash flow has a positive effect on agency cost. Meanwhile, the second research model is used to examine the $\mathrm{H} 2$ hypothesis, namely free cash flow has a negative effect on financial performance. The research design can be seen in the following figure. 


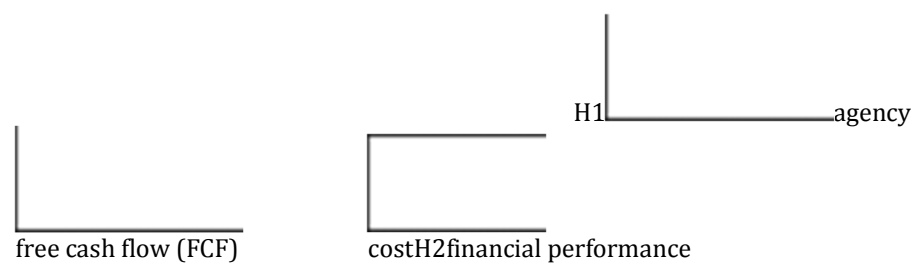

\subsection{Population and Sample}

The population is a collection of individuals. According Sekaran $(2006,121)$, population(population)refers to a whole group of people, events or things to researchers investigating. The population in this study were 83 companies listed on the Indonesian Stock Exchange in the financial sector. The(sample sample) is part of the population. Sekaran (2006, 123) states that the sample consists of a number of members selected from the population. The sample used in this study are companies in the financial sector that have certain criteria. The sampling method used is purposive sampling,sampling namely is carried out based on the following criteria: (1) Financial sector companies listed on the Indonesia Stock Exchange in 2015 and 2016. (2) The number of financial companies that have just IPOs over 2015. (3) Financial Companies that have incomplete data.

Based on these criteria, the sample obtained is 61 companies.

\subsubsection{Research}

Instruments The research instrument is a tool used to obtain data. In this study, the authors used a questionnaire instrument in the form of an interview guide. In this case the writer uses general guidelines interview by making a outline and outline of the things that will be asked of the respondents in the interview process. The interview guide that is made contains questions that lead to the formulation of research problems.

\subsubsection{Data Collection Techniques}

Based on how to obtain data, this type of research data is secondary data. Data in the form of financial reports and company annual reports are obtained from the website the Indonesia Stock Exchange(http://www.idx.co.id/). The data used in this research is data time series. Furthermore in the data will be carried pemanelan golahan of data(pooled data)are combined Peng process data. It is said to be combined data because this data consists of several objects / sub- objects in several time periods.

\section{Result and Discussion}

\subsection{The Effect of Free Cash Flow (FCF) on Asset Turnover (ACTO)}

The results showed that the FCF variable (X) had a positive and significant effect on the ACTO variable (Y), where if the FCF value was greater then the ACTO value would be greater, and the results The research also shows that the variable $\mathrm{x}$ is able to explain the variabley. The results show that the FCF has a positive influence on the ACTO, this indicates that there is an influence between corporate management that is implemented in company control so that it can increase ACTO, so that with a significant influence between FCF on ACTO, there is a relationship between holding shares and management. This influence can be shown by the data 
in the results of this study from the company (Asuransi Dayin Mitra Tbk) which shows that in 2015-2016 each has a higher free cash flow value followed by a higher asset turnover value.

The results of the influence are also in accordance with agency theory, where the results of the positive and significant influence between the FCF and the ACTO are in accordance with the principles of agency theory which states that there is a working relationship between the party who gives the authority (principle), namely the owner or shareholder and the party receiving the authority ( agent) namely the manager, in the form of a cooperation contract (Elqorni, in Primasari, 2011).

The results of this study are supported by research conducted by Yasa and Dewi (2016) with proxies for selling and general administrative and asset turnover, Piramita (2012) with proxies for asset turnover and administration ratio, Aprillya (2017) with proxies for ACTO (asset turnover) and OPEXR. (operating expense ratio). which states that free cash flow has a positive effect on agency cost. Where the higher the free cash flow, the higher the agency cost. However, this research contradicts Basuki's (2016) study where free cash flow has a significant and negative effect on agency cost which is proxied by asset turnover turnover, agency cost which is proxied by asset has a significant and negative effect on firm value and free cash flow. has a significant and positive effect on firm value through agency cost.

\subsection{The Effect of Free Cash Flow (FCF) on Return On Assets (ROA).}

The results showed that the variable FCF $(\mathrm{X})$ is positive and significant, meaning that there is a positive effect of FCF on ROA, and the results also show that the variable $\mathrm{x}$ is able to explain the variable $y$.

Based on the results of this study, the influence is in accordance with agency theory where there is a relationship between investors and management, with the influence of the company's FCF obtained by the company management can still control and do not take advantage of the benefits of the FCF so that it does not experience a decline in company performance. According to Arifin (2006: 7-8) agency theory is based on a contractual relationship between members in a company, where the principal and the agent are the main actors. The principal is the party who gives power or authority to the agent to act on behalf of the principal, while the agent is the party who is mandated by the principal to run the company. Thus, a good work contract between the principal and the agent is a work contract that explains what the manager must do in managing the invested funds and the profit sharing mechanism in the form of profits, returns and risks that have been agreed by both parties. This influence can be shown by the data in this study from the company (Bank Woori Saudara Indonesia) which shows that in 2015-2016 each has a higher free cash flow value, and is followed by a higher return on assets value.

The results of this study are supported by research conducted by Piramita, 2012 which states that free cash flow has a positive effect on financial performance using proxies of return on assets (ROA) and return on equity (ROE). Where the higher the free cash flow, the higher the impact on financial performance. Brush et al (2000) found that sales growth was most beneficial for companies with a lack of cash flow, but not necessarily for companies with free cash flow sufficient. Chung et al (2005) also found that excessive FCF may have a negative impact on firm profitability and stock valuation and thus increase agency costs. The findings of Wang (2010) that free cash flow has a significant positive effect on ROA and ROE. This 
contradicts the theory put forward by Freud et al. (2006) stated that there was a negative relationship between free cash flow and operating performance. Brush et al. (2000) also stated that an increase in free cash flow will reduce the sales growth performance, which is proxied by ROA. So in this case the manager is able to manage free cash flow well. So that it does not cause harm to the company.

\section{Conclusion}

Based on the results and discussion obtained in this study are as follows: (1) Free cash flow (FCF) has a positive and significant effect on agency cost in financial sector companies listed on the IDX 2015-2016. This means that if a company in the financial sector has free cash flow a large, then the agency cost (asset turnover) of the company will also increase. (2) Free cash flow (FCF) has a positive and significant effect on financial performance in financial sector companies listed on the IDX 2015-2016. This means that if a company in the financial sector has free cash flow a large, then its financial performance (return on assets) will increase.

The suggestions for further research are: (1) The next researcher can use more than 1 variable which can affect the y variable. (2) Perform tests using proxies for agency costs different such as income volatility, operatingincome volatility, and research and development expense ratio.

\section{References}

Mawarni, D., \& Abdullah, S. (2013). Pengaruh Pendapatan Asli Daerah dan Dana Alokasi Umum terhadap Belanja Modal serta Dampaknya terhadap Pertumbuhan Ekonomi Daerah (Studi pada Kabupaten dan Kota di Aceh). Jurnal Akuntansi ISSN, 2302, 0164.

Agustia, D. (2013). Effect of Free Cash Flow and Audit Quality on Earnings Management. Faculty of Economics and Business, Airlangga University. Akrual 4 (2) (2013) 105 - 118 e - ISSN: 2502 - 6380

Anoraga, P. and Pakarti, P. (2006). Introduction to Capital Markets. Revised Edition. Jakarta: Rineka Cipta.

Arifin, Zaenal. (2006). Theory of Finance and Capital Markets, Yogyakarta: EKONESIA Arilaha, MA 2009. "The Effect of Free Cash Flow, Profitability, Liquidity, and Leverage on Dividend Policy". Journal of Finance and Banking, Vol. 13, No. 1.

Atmaja, L. S. (2008). Financial Management Theory and Practice. Yogyakarta: CV. Andi Offset.

Brigham, Eugene F and Joel F. Houston, (2010). Basics of Financial Management, translation of Ali Akbar Yulianto, Eleventh Edition, Volume I \& II, Salemba Empat, Jakarta.

Brigham, Eugene F and Joel F. Houston. (2006). Basics of Financial Management, Linguist Akbar Yulianto. Book One, Issue Ten. PT. Four Salemba. Jakarta.

Brush, T. H., Bromiley, P., \& Hendrickx, M. (2000). The free cash flow hypothesis for sales growth and firm performance. Strategic management journal, 21(4), 455-472.

Chu, J. (2011). Agency cost under the restriction of free cash flow. Journal of Service Science and Management, $4(01), 79$.

Chung, R., Firth, M. and Kim, JB (2006). Earnings Management, Surplus Free Cash Flow, and External Monitoring. Journal of Business Research, 58, 766 - 776.

Early. (2007). "The Effect of Free Cash Flow on Dividend Payout Ratio". Journal of Accounting and Management, vol. 3, no. 2 .

Donald E. Kieso, Jerry J, Weygandt, Terry D.Warfield. (2008). Accounting. Intermediate. 12. Jakarta Edition: Erlangga

Elizabeth, (2007). "Analysis of Accounting Profits, Operating Cash Flow with Cash Dividends at Companies Going Public on the JSE", Thesis, Faculty of Economics, University of Indonesia, Bogor.

Fachrudin, K. Amalia. (2009). Analysis of the Effect of Capital Structure, Company Size, and Agency Cost on Company Performance. Journal of Accounting and Finance, Vol 13, No. 1, May 2009, 37 -46 
Fees, Warren, Reeve. (2012). Introduction to Accounting, Salemba Empat, Jakarta Fosberg et al. 2006. Agency Cost Control. Journal of the American Academy of Business. Cambridge. P. 299.

Freund, S., AP Prezas, and GK Vasudevan, (2006). Operating Performance and Free Cash Flo w of Asset Buyers. Financial Management (winter), pp. 87 - 106.

Guinan, Jack, (2010). Investopedia: Easy Ways to Understand Investment Terms. South Jakarta: Hikmah (Translator Yanto Kusdianto)

Guinan, Jack. (2010). Investopedia: Easy Ways to Understand Investment Terms. Jakarta: Wisdom.

Gul, F. A., \& Tsui, J. S. L. (1997). A test of the free cash flow and debt monitoring hypotheses: Evidence from audit pricing. Journal of Accounting and Economics, 24(2), 219-237.

Hadi, Nor. (2013). Capital Market. Yogyakarta: Graha Science.

Hadi prajitno, Paulus Basuki. (2013). Ownership Structure, Corporate Governance Mechanism, and Agency Costs in Indonesia. Journal of Accounting \& Auditing. Volume 9 / No. 2 / MAY 2013: 97 - 127

Husnan, Suad and Pudjiastuti, Enny. (2006). Fundamentals of Financial Management. Yogyakarta: UPP STIM YKPN.

Husnan, S. (2009). The basics of Portfolio Theory and the analysis of securities. Yogyakarta: UPP STIM YKPN.

IGKA Ulupui, (2009). The Effect of Analysis of the Effect of Liquidity Ratios, Leverage, Activity, and Profitability on Stock Returns (Studies on food and beverage companies on the JSE), Thesis, Department of Accounting, Faculty of Economics, University of Udayana.

Jensen, M. C. (1986). Agency costs of free cash flow, corporate finance, and takeovers. The American economic review, 76(2), 323-329.

Keown, et al. (2008). Financial Management, 7th edition, translated by Djakman and Su listyorini, Publisher Salemba Empat, Jakarta.

Mardhatillah, Novita. (2013). Marketing Communication in The Process Of Buying And Selling Online Through BlackBerry Messenger Features. Padjadjaran University.

Mulyadi, (2005). Cost Accounting. Fifth Edition. Yogyakarta; UPP AMP YKPN.

Nugroho, Aga. (2012). The Effect of Ownership Structure and Corporate Governance Mechanisms on Agency Cost. Journal of Accounting, Vol 1, No 1, 2012, 1-3.

Prihadi, T. (2012). Understanding Financial Statements in Accordance with IFRS and PSAK. Jakarta: PPM Management

Primasari, BP (2011). Analysis of the Influence of Managerial Ownership, Management Ownership, Institutional Ownership, and Funding Decisions on Firm Value. Thesis. Sebelas Maret University Faculty of Economics. Surakarta.

Purdwiastuti, MM \& Nofiyanti, R. (2013). Agency Fees and Dividend Policy: Implications of Business Group Affiliates. UG Journal Vol. 6 No. 02.

Rahman and Fitriasari, Rizka. (2012). The Effect of Free Cash Flow Agency Problems and Independent Commissioners on the Value Relevance of Accounting Information. Multiparadigma Journal. Brawijaya University. Vol. 3, No. 1. ISSN 2086 - 7603.

Richardson, S. (2006). Over-investment of free cash flow. Review of accounting studies, 11(2-3), 159-189.

Sartono, A. (2008). Financial Management Theory and Applications. Issue Four. Yogyakarta: BPFE.

Uma, S. (2006). Research Methodology for Business. Journal: Salemba Four. 1, 2(4).

Sujoko, K., \& Soebiantoro, U. (2007). Effect of Shareholding Structure, Leverage, Internal and External Factors Against company value. Journal of Management and Enterpreneurship, 9(1), 41-48.

Susanto, San and Erni Ekawati, (2006). "The Relevance of Earnings and Information Value Cash Flow to Stock Price in Relation to Company Life Cycle", National Accounting Sim Posium IX. Padang.

Susilawati, RAE (2010). Analysis of Free Cash Flow and Managerial Ownership of Debt Policy in Public Companies in Indonesia. Journal of Economics MODERNIZATION, Volume 6, Number 2, June 2010.

Tandelilin, E. (2010). Portfolio and investment theory and application. Yogyakarta: Kanisius. 
Jurnal Ekonomi, Bisnis dan Pendidikan, 1(4), 2021, 305-312

Toto Prihadi. (2012). Understanding Financial Statements in Accordance with IFRS and PSAK. PPM. Management. Jakarta

Wang, G. Y. (2010). The impacts of free cash flows and agency costs on firm performance. Journal of service science and management, 3(04), 408.

Wicaksono, Frans Sastro, (2009). Responsibilities of Shareholders, Directors and Committees of Limited Liability Companies (PT). Visi Media, Jakarta.

Yuan, J., \& Jiang, Y. (2008). Accounting information quality, free cash flow and overinvestment: A Chinese study. 